\title{
Multipl Skleroz Hastalarında Metilprednizolon ve İnterferon Tedavisinin Kan Vitamin B12, Folik Asid ve Homosistein Düzeyleri Üzerine Etkisi
}

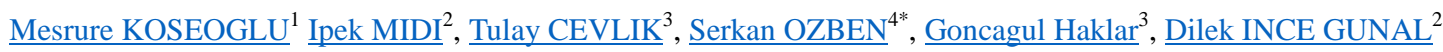

\begin{abstract}
Öz
Multipl Skleroz (MS) hastalığının seyrinde ve tedavi sürecinde homosistein, vitamin B12 ve folik asit düzeylerindeki değişiklikler bildirilmiş ancak tam mekanizması aydınlatılamamıştır.Çalışmamızda, akut atak ile başvuran hastalarda yüksek doz metilprednizolon tedavisi öncesinde, sonrasında ve interferon- $\beta$ tedavisi sonrasında serum B12, folik asit ve homosisitein düzeylerindeki değişiklikler incelenmiştir. Çalışmaya 1 yıl içinde akut atak ile başvuran, klinik kesin MS tanısı konarak takip edilen 31 hasta (8 erkek, 23 kadın) ve 10 kontrol olgusu dahil edildi. 20 hasta akut atak ile başvurdu 7 gün süreyle $1000 \mathrm{mg} /$ gün metilprednizolon uyguland. 27 hastaya interferon- $\beta$ tedavisi başlandı. Yüksek doz steroid tedavi sonrası 1 . ay düzeyleri ve interferon- $\beta$ tedavisi alan hastaların 3 . ay sonundaki serum vitamin B12, folik asit ve plazma homosistein düzeyleri ölçülerek kontrol grubu ve tedavisi öncesi düzeyleri ile karşılaştırıldı. Kontrol grubuna göre MS hastalarının bazal B12 değerleri daha önceki bulgularla tutarlı olarak daha düşüktü. Hem metilprednizolon, hem de interferon- $\beta$ tedavisi sonrası B12 ve folik asid değerlerinde yükselme saptand 1 ancak sadece metilprednizolon tedavisi sonrasındaki artış istatiksel olarak anlamlıydı. Çalışmamızda saptanan metilprednizolon sonrası yükselen B12 ve folik asid düzeyleri ve istatistiksel anlamlılığa ulaşmayan homosistein düzeylerindeki düşme eğilimi farklı tartışmalar yaratmaktadır.
\end{abstract}

Anahtar Kelimeler: Multipl skleroz, metilprednizolon, interferon- $\beta$, vitamin B12, folik asit, homosistein
Yayın Bilgisi

Gönderi Tarihi: 22.10.2018

Kabul Tarihi: 29.10.2018

Online Yayın Tarihi: 30.09.209

DOI: $10.26453 /$ otjhs. 472020

Sorumlu Yazar

Serkan OZBEN

Department of Neurology, Antalya

Training and Research Hospital, Antalya, Turkey

Tel: +902422494400 ,

e-Mail: serkanozben@yahoo.com

Effect of Methylprednisolone and Interferon Treatment on Blood Vitamin B12, Folic Acid and Homocysteine Levels in Patients with Multiple Sclerosis

$\underline{\text { Mesrure KOSEOGLU }}^{1} \underline{\text { Ipek MIDI }}^{2}, \underline{\text { Tulay CEVLIK }}^{3}, \underline{\text { Serkan OZBEN }}^{4 *}, \underline{\text { Goncagul Haklar }}^{3}, \underline{\text { Dilek INCE GUNAL }}^{2}$

\begin{abstract}
Changes in blood homocysteine, vitamin B12 and folic acid levels have been reported during multiple sclerosis (MS) and treatment period; however, the exact mechanism has not been enlightened. We investigated the changes of serum B12, folic acid, and plasma homocysteine levels before and after high-dose IV methylprednisolone treatment and after interferon- $\beta$ treatment in patients admitted with an acute attack of MS.31 patients followed for clinically definite MS (8 male, 23 female) and 10 control individuals were included in the study. 20 patients were admitted with an acute attack and were administered $1000 \mathrm{mg} /$ day methylprednisolone for 7 days. 27 patients started interferon- $\beta$ treatment. Serum B12, folic acid, and plasma Homocysteine levels measured before and after the 1 month after high dose steroid treatment and after 3-month interferon- $\beta$ treatment were compared with pre-treatment levels and healthy controls. Baseline B12 levels were lower in patients with MS than in healthy controls, which is consistent with previous findings. Both methylprednisolone and interferon- $\beta$ treatments increased serum B12 and folic acid levels compared with baseline; however, only the increase following methylprednisolone treatment was statistically significant.In our study, elevated B12 and folic acid levels and decreasing of homocysteine levels without reaching statistical significance following methylprednisolone have caused different debates.
\end{abstract}

Article Info

Received: 22.10 .2018

Accepted: 29.10.2018

Online Published: 30.09 .2019

DOI: $10.26453 /$ otjhs. 472020

Corresponding Author Serkan OZBEN

Department of Neurology, Antalya

Training and Research Hospital, Antalya, Turkey

Tel:+90 2422494400 ,

e-Mail: serkanozben@yahoo.com

Keywords: Multiple sclerosis, methylprednisolone, interferon-beta, vitamin B12, folic acid, homocysteine

\footnotetext{
${ }^{1}$ Department of Neurology, Bakirkoy Psychiatry and Neurology Research and Training Hospital, Istanbul, Turkey

${ }^{2}$ Department of Neurology, Marmara University Hospital, Istanbul, Turkey

${ }^{3}$ Department of Biochemistry, Marmara University Hospital, Istanbul, Turkey

${ }^{4}$ Department of Neurology, Antalya Training and Research Hospital, Antalya, Turkey
} 


\section{INTRODUCTION}

Multiple sclerosis (MS) is a chronic central nervous system (CNS) disorder. It is thought to be caused by a combination of autoimmune mechanisms and complex interactions between genetic and environmental factors and is characterized by inflammation, demyelination, and axonal injury. ${ }^{1}$

The relationship between MS and vitamin B12 was first investigated more than 40 years ago; however, because of subsequent, primarily cross-sectional case-control, studies and methodological difficulties, the relationship is not well understood. The initial studies examined only vitamin B12 levels, whereas more recent studies have investigated vitamin B12 in conjunction with homocysteine (Hcy) levels in blood and cerebrospinal fluid. ${ }^{2-6}$

MS and vitamin B12 deficiency have some common pathophysiological features, such as inflammation and neurodegeneration. Furthermore, similarities in the clinical manifestation and magnetic resonance imaging (MRI) findings of the conditions make differential diagnosis difficult. Low or decreased serum and CSF vitamin B12 levels have been reported in patients with MS; however, other studies found an increase in plasma Hcy levels with no decrease in vitamin B12. ${ }^{7-12}$

Recent studies have investigated the role of Hcy metabolism dysfunction in the pathogenesis of MS as well as the relationships among vitamin B12, folic acid, and Hcy levels and treatment with high-dose MP, immunomodulatory agents, and immunosuppressive agents. ${ }^{11}$

We assessed the changes in serum vitamin B12, folic acid, and plasma Hcy levels before and after acute treatment with high-dose IV methylprednisolone (MP) and following maintenance treatment with interferon-beta (INF-ß).

\section{MATERIALS AND METHODS}

Patients ( $n=31$, age range, $18-49$ years) admitted to the Department of Neurology, Medical Faculty of Marmara University (MFMU) over a 1-year period with a definitive diagnosis of relapsing-remitting MS (RRMS) according to the McDonald Diagnostic Criteria were included in the study. ${ }^{13}$ The study protocol was approved by the Marmara University Medical Faculty Ethics Committee (B.30.2.MAR.0.01.00.02/AEK-285) and written consent was obtained from all patients. The patients were compared with age- and sex-matched healthy control subjects.

Exclusion criteria included: previous immunomodulatory therapy; replacement therapy with vitamin B12 and/or folic acid; presence of other diseases that may have affected vitamin B12, folic acid and/or Hcy levels (i.e., gastrointestinal disorders, renal 
failure, gout, diabetes mellitus, hypothyroidism, rheumatoid arthritis, systemic lupus, psoriasis, HIV/AIDS, cancer); use of medications that increase Hcy levels (antiepileptics, levodopa, antihyperlipidemics, diuretic antihypertensives, cyclosporine, erythropoietin, isoniazid, lithium, methotrexate, neuroleptics, nitroglycerin, nitrous oxide, oral antidiabetics, oral contraceptives, sulphasalazine, theophylline, trimethoprim); and chronic high alcohol consumption.

Physical and neurological examinations were administered to patients that met the inclusion criteria who were first-time visitors to our clinic. All patients underwent routine blood tests and tests for differential diagnosis (i.e., complete blood count, liver function test, renal function test, thyroid function test, lipid profile, antinuclear antibody, anticardiolipin IgG and IgM, thrombosis panel, syphilis, HIV and brucella serology). Lumbar puncture and MRI (cranial and, if needed, spinal) were also performed and Expanded Disability Status Scale (EDSS) scores were calculated. ${ }^{13}$

Patients with clinical symptoms lasting more than $24 \mathrm{~h}$ received MP $1000 \mathrm{mg} /$ day IV for 7 days, followed by maintenance therapy with immunomodulatory agents (Interferon beta-1a [Avonex, Rebif], Interferon beta- $1 \mathrm{~b}$ [Betaferon]) as indicated clinically.

A venous blood sample (10 cc) was obtained from the forearm of all patients between 8 and
10 am after overnight fasting and was analyzed in the Marmara University Medical Faculty biochemistry laboratory for the following parameters:

a) serum vitamin B12, folic acid, and plasma Hcy levels before and 7-10 days after steroid treatment. ( $n=20$ patients $)$

b) serum vitamin B12, folic acid, and plasma Hcy levels 3 months following INF- $\beta$ treatment $(n=16)$

c) serum vitamin B12, folic acid, and plasma Hcy levels before and 3 months after INF- $\beta$ treatment in patients receiving immunomodulatory therapy alone $(n=11)$

\section{Homocysteine measurements}

Blood samples were collected into standard test tubes with EDTA to measure total plasma Hcy (tHcy). Samples were initially stored at 2$80^{\circ} \mathrm{C}$ and centrifuged within $30 \mathrm{~min}$. The plasma was separated and stored at $-80^{\circ} \mathrm{C}$ until analysis at the end of the study.

Plasma contains several forms of Hcy. In healthy subjects, $1-2 \%$ of Hcy is in the free reduced form (HcySH), and $10-30 \%$ is in the low-molecular-weight disulfide form, homocysteine disulfide (HcySSHcy), or mixed with other low-molecular-weight thiols such as cysteine and gluthatione (HcySSR), whereas $70-80 \%$ of plasma Hcy is bound to proteins with disulfide bonds (HcyS-protein). In biological samples, tHcy refers to all Hcy forms. Thus, Hyc measurement techniques follow a strategy that involves the reduction of 
all disulfide forms to free thiol derivatives and precipitation of the proteins present in the sample matrix. ${ }^{14}$

We measured plasma Hcy levels using the gold standard high performance liquid chromatography (HPLC) method.

\section{Vitamin B12 and folic acid measurements}

Blood samples for vitamin B12 and folate were collected into empty tubes, centrifuged within $30 \mathrm{~min}$ of withdrawal, and kept at $80^{\circ} \mathrm{C}$ until assayed. Serum vitamin B12 and folate levels were measured using electrochemiluminescence (ECLIA) using an Elecsys 2010 modular analytics E170 immunochemistry analyzer. Normal adult ranges set at the Biochemistry Laboratory of Marmara University Medical Faculty were taken as the reference values as follows: Hcy 5-14 $\mu \mathrm{mol} / \mathrm{L}$, vitamin B12 191-663 pg/mL, folic acid 3.1-17.5 ng/mL (7.0-39.7 nmol/L).

\section{Statistical analyses}

All data analyses were conducted using the Statistical Package for Social Sciences for Windows, version 10.0 (SPSS Inc., Chicago, IL, USA). Results are expressed as means \pm standard deviation. Paired $t$-tests and nonparametric Wilcoxon signed-rank tests were used for comparisons. A $p$-value $<0.05$ was considered to indicate statistical significance.

\section{RESULTS}

A total of 31 patients with RRMS between the ages of 18 and 49 ( 8 male, 23 female) were included in the study. Of the 31 patients, 20 were admitted with an acute attack and were administered MP (1000 mg/day IV) for 7 days. Of those, 16 subsequently received maintenance immunomodulatory therapy (Avonex, $n=6$; Rebif, $n=5$; Betaferon, $n=$ 5). The remaining 4 patients did not receive maintenance therapy for the following reasons: one patient refused treatment, one had no health insurance and could not afford the cost of the treatment, and the clinical course was benign in two patients. Eleven patients did not have an acute attack but were considered suitable for immunomodulatory therapy. Patient demographic are shown in (Table 1). Serum vitamin B12 levels were significantly lower in patients with MS prior to MP treatment $(342.73 \pm 116.27 \mathrm{pg} / \mathrm{mL})$ than in healthy control subjects $(502.89 \pm 191.78$ $\mathrm{pg} / \mathrm{mL} ; p<0.001)$. However, baseline serum folic acid and plasma Hcy levels were not significantly different between groups.

Pre- and post- IVMP-treatment levels of serum vitamin B12 and folic acid are shown in (Table 2). Post-treatment vitamin B12 and folic acid levels were significantly higher than pretreatment values $(p<0.05)$, whereas no significant difference was found between preand post-treatment plasma Hcy levels $(p>$ $0.05)$.

Patients who received INF- $\beta$ maintenance therapy following acute MP treatment showed an increase in vitamin B12 levels at the end of 
the 3-month treatment period compared with pre-MP treatment values. However, the difference did not reach statistical significance $(p>0.05)$; (Table 3). Compared with pre-MP treatment values, vitamin B12 levels increased after both MP and INF- $\beta$ treatments; however, the increase in vitamin B12 after MP treatment was significant $(p<0.009)$, whereas that following INF- $\beta$ treatment was not $(p=$ 0.232); (Figure 1).

We found no significant differences pre-and post- INF- $\beta$ treatment regarding plasma Hcy or serum vitamin B12 and folic acid levels in patients who did not receive MP but met the criteria for INF- $\beta$ treatment $(p>0.05)$; $($ Table 4).

\section{DISCUSSION}

Our results indicate a significant increase in serum vitamin B12 levels and a nonsignificant decrease in plasma Hcy levels in patients following a 7-day treatment regimen of IV MP following an acute attack of MS. Serum vitamin B12 levels showed a slight, but non-significant increase following maintenance treatment with INF- $\beta$ for 3 months, and no change in plasma Hcy levels.

Early investigations reported decreased levels of vitamin B12 in patients with MS compared with healthy controls, and subsequent studies of vitamin B12 and Hcy levels revealed an increase in Hcy and a decrease in vitamin B12 in serum and $\mathrm{CSF}^{9-16}$ Recent studies have examined the role of dysfunctional Hcy metabolism in the pathogenesis of MS, whereas others, such as our study, focused on the effect of MS treatment on vitamin B12, folic acid, and Hcy levels. ${ }^{9,10,17}$ However, few researchers have investigated this relationship. In 1993, Frequin et al. reported a significant decrease in CSF vitamin B12 levels, and a tendency toward reduced serum levels, in patients with MS receiving high-dose MP treatment. $^{11}$

Our finding of increased serum vitamin B12 and a non-significant decrease in plasma Hcy levels following high-dose MP treatment may reflect an acute effect of the steroid on vitamin B12 metabolism. It may be that the steroid increases vitamin B12 absorption, thus suppressing enzymatic processes in which vitamin B12 acts as a co-factor. Alternatively, the steroid may prevent the breakdown of vitamin B12. Furthermore, high-dose steroid treatment may inhibit the production of autoantibodies against intrinsic factor or parietal cells and, therefore, increase the absorption of vitamin B12, leading to an increase in serum levels of the vitamin. Acute high-dose MP treatment has been shown to suppress inflammation and delay repair mechanisms, reducing availability of vitamin B12 for the repair process during the acute period. Thus, it is possible that acute corticosteroid treatment increases serum vitamin B12 levels. 
Our finding that INF- $\beta$ treatment alone did not change vitamin B12 levels supports the theory that the increase in vitamin B12 levels was induced by the steroids. Moreover, the fact that a 3-month treatment regimen with INF- $\beta$ did not significantly increase vitamin B12 levels over those generated by acute MP treatment further supports a steroid-mediated mechanism. Our small sample size may account for the non-significant change in Hcy levels.

INF- $\beta$ or immunosuppressive treatment in MS causes a shift from Th1 toward the Th2 immune response. ${ }^{18-21}$ A shift toward the Th2 immune profile is associated with an increased risk of humoral immunity, which may increase predisposition to antibody-mediated autoimmune diseases. An increase in antinuclear, antismooth muscle, and other autoantibody levels and an increased risk of subacute thyroiditis and Graves' disease have been reported in patients receiving IFN- $\beta .^{22-26}$ Furthermore, the Th2 autoimmune disorder results in the development of autoantibodies specific for parietal cells or intrinsic factor causing pernicious anemia, which is associated with vitamin B12 deficiency. ${ }^{21}$

In a recent study, Miller et al. reported a significant decrease in serum vitamin B12 levels in patients with MS treated with IFN$\beta .^{27}$ However, rather than the induction of autoantibodies, the authors attributed the decrease to the suppression of the inflammatory processes together with increased repair process associated with vitamin B12.

Mastronardi et al. showed that the combination of IFN- $\beta$ and vitamin B12 resulted in a dramatic improvement in all clinical, histological, and laboratory parameters in in vivo models of demyelinating disorders. ${ }^{28}$

Although the sample size was small, our data showed a significant increase in serum vitamin B12 and folic acid levels following treatment with MP $(p=0.009)$. Subsequent maintenance therapy with IFN- $\beta$ did not change Hcy or folic acid levels; however, serum vitamin B12 levels were increased compared with the preMP treatment values, although the difference was not statistically significant $(p=0.232)$.

\section{CONCLUSION}

In conclusion, our results suggest that MP treatment may influence vitamin B12 metabolism that persists during the acute stage of subsequent INF- $\beta$ treatment. We investigated the levels of vitamin B12 and its metabolites in patients treated for an acute attack of MS with IV MP and maintenance immunomodulatory therapy. Few previous studies have investigated this issue. The small sample size and short follow-up period of 3 months are the primary limitations of our study; however, several mechanisms may 
explain the marked increase in serum vitamin B12 levels after MP treatment.

\section{REFERENCES}

1. Huseyinoglu N, Ekinci $M$, Ozben $S$, Buyukuysal C. Relationship between Structural and Functional Assessment of the Visual System in Mildly Disabled Relapsing-Remitting Multiple Sclerosis Patients. Neuroophthalmology. 2014;38(1):1-7.

2. Ramsaransing GS, Fokkema MR, Teelken A, Arutjunyan AV, Koch M, De Keyser J. Plasma homocysteine levels in multiple sclerosis. J Neurol Neurosurg Psychiatry. 2006;77(2):189-192.

3. Simpson CA. Vitamin B12 levels in the serum and cerebrospinal fluid in multiple sclerosis. J Neurol Neurosurg Psychiatry. 1964;27:174-177.

4. Oliveira SR, Flauzino T, Sabino BS, et al. Elevated plasma homocysteine levels are associated with disability progression in patients with multiple sclerosis. Metab Brain Dis. 2018;33(5):1393-1399.

5. Dardiotis E, Arseniou S, Sokratous M, et al. Vitamin B12, folate, and homocysteine levels and multiple sclerosis: A metaanalysis. Mult Scler Relat Disord. 2017;17:190-197.

6. Nijst TQ, Wevers RA, Schoonderwaldt HC, et al. Vitamin B12 and folate concentrations in serum and cerebrospinal fluid of neurological patients with special reference to multiple sclerosis and dementia. J Neurol Neurosurg Psychiatry. 1990;53:951-954.

7. Reynolds EH, Linnell JC, Faludy JE. Multiple sclerosis associated with vitamin B12 deficiency. Arch Neurol. 1991;48:808811.

8. Reynolds EH, Bottiglieri T, Laundy M, et al. Vitamin B12 metabolism in multiple sclerosis. Arch Neurol. 1992;49:649-652.

9. Besler HT, Comoğlu S. Lipoprotein oxidation, plasma total antioxidant capacity and homocysteine level in patients with multiple sclerosis. Nutr Neurosci. 2003;6:189-196.

10. Vrethem M, Mattsson E, Hebelka H, et al. Increased plasma homocysteine levels without signs of vitamin B12 deficiency in patients with multiple sclerosis assessed by blood and cerebrospinal fluid homocysteine and methylmalonic acid. Mult Scler. 2003;9:239-245.

11. Frequin ST, Wevers RA, Braam M, Barkhof F, Hommes OR. Decreased vitamin B12 and folate levels in cerebrospinal fluid and serum of multiple sclerosis patients after intravenous methylprednisolone. J Neurol. 1993;240:305-308.

12. Khosravi-Largani M, Pourvali-Talatappeh P, Rousta AM, et al. A review on potential roles of vitamins in incidence, progression, and improvement of multiple sclerosis. 
eNeurologicalSci. 2018;10:37-44.

13. McDonald WI, Compston A, Edan G, et al. Recommended diagnostic criteria for multiple sclerosis: guidelines from the international panel on the diagnosis of multiple sclerosis. Ann Neurol. 2001;50:121-127.

14. Ansari R, Mahta A, Mallack E, Luo JJ. Hyperhomocysteinemia and neurologic disorders: a review. J Clin Neurol. 2014;10(4):281-288.

15. Qureshi GA, Halawa A, Baig S, et al. Multiple sclerosis and neurotransmission. Biogenic Amines. 1996;12:353-376.

16. Baig SM, Qureshi GA, Minami M. The interrelation between the deficiency of vitamin B12 and neurotoxicity of homocysteine with nitrite in some of neurologic disorders. Biogenic Amines. 1998;14:1-14.

17. Ramsaransing GS, Fokkema MR, Teelken A, et al. Plasma homocysteine levels in multiple sclerosis. J Neurol Neurosurg Psychiatry. 2006;77:189-192.

18. Smith DR, Balashov KE, Hafler DA, et al. Immune deviation following pulse cyclophosphamide/methylprednisolone treatment of multiple sclerosis: increased interleukin-4 production and associated eosinophilia. Ann Neurol. 1997;42:313318.

19. Miller A, Shapiro S, Gershtein R, et al. Treatment of multiple sclerosis with copolymer-1 (copaxone): implicating mechanisms of Th1 to Th2/Th3 immunedeviation. J Neuroimmunol. 1998;92:113-121.

20. Kozovska ME, Hong J, Zang YC, et al. Interferon beta induces T-helper 2 immune deviation in MS. Neurology. 1999;53:16921697.

21. Borgia G, Reynaud L, Gentile I, et al. Pernicious anemia during IFN-alpha treatment for chronic hepatitis C. J Interferon Cytokine Res. 2003;23:11-12.

22. Haji Abdolvahab M, Mofrad MR, Schellekens H. Interferon Beta: From Molecular Level to Therapeutic Effects. Int Rev Cell Mol Biol. 2016;326:343-372.

23. Durelli L, Ferrero B, Oggero A, et al. Autoimmune events during interferon beta 1b therapy for multiple sclerosis. J Neurol Sci. 1999;162:74- 83.

24. Kreiss Y, Cohen O, Pras E, et al. Subacute thyroiditis in a patient with multiple sclerosis treated with interferon beta 1a. Neurology 1999;53:1606.

25. Lange-Asschenfeldt C, Boor S, Kahaly GJ, Thömke F. [Autoimmune functional disorders of the thyroid during interferonbeta- $1 \mathrm{~b}$ treatment in patients with multiple sclerosis. Case report and literature review]. Nervenarzt. 2004;75(6):589-94.

26. Rotondi M, Mazziotti G, Biondi B, et. Long-term treatment with interferon beta therapy for multiple sclerosis and 
occurrence of Graves' disease. J Endocrinol

Invest. 2000; 23:321- 324.

27. Miller A, Korem M, Almog R, et al. Vitamin B12, demyelination, remyelination and repair in multiple sclerosis. $\mathbf{J}$ Neurol Sci. 2005;233:93-97.

28. Mastronardi FG, Min W, Wang H, et al. Attenuation of experimental autoimmune encephalomyelitis and non-immune demyelination by IFN-beta plus vitamin B12: treatment to modify notch-1/sonic hedgehog balance. J Immunol. 2004;172:6418-6426. 
Table 1. Patients' demographic characteristics.

\begin{tabular}{lcc}
\hline & \multicolumn{2}{c}{ Treatment } \\
\hline MP + INF- $\beta$ & INF- $\beta$ alone \\
\hline Patients, $\boldsymbol{n}$ & 16 & 11 \\
Aex $(\mathbf{M} / \mathbf{F})$ & $4 / 12$ & $3 / 8$ \\
Ege, median (range) & $31.7(22-49)$ & $36(23-48)$ \\
EDSS, median (range) & $1.95(1-3.5)$ & $0.6(0-1)$
\end{tabular}

MP, methylprednisolone; INF- $\beta$, interferon-beta; EDSS, Expanded Disability Status Scale. 
Table 2. Plasma homocysteine and serum vitamin B12 and folic acid levels before and after methylprednisolone (MP) treatment (1000 mg/day IV for 7 days) (Steroid +).

\begin{tabular}{lccc}
\hline$(\boldsymbol{n}=\mathbf{2 0})$ & Pre MP & Post MP & \\
& Mean \pm SD & Mean \pm SD & P* \\
\hline Homocysteine $(\mathbf{m m o l} / \mathbf{L})$ & $8.96 \pm 3.50$ & $8.24 \pm 2.06$ & 0.294 \\
Vitamin B12 $(\mathbf{p g} / \mathbf{m L})$ & $342.73 \pm 116.27$ & $410.81 \pm 135.28$ & $\mathbf{0 . 0 0 9 *}$ \\
Folic acid $(\mathbf{n g} / \mathbf{m L})$ & $6.46 \pm 1.24$ & $7.51 \pm 1.39$ & $\mathbf{0 . 0 1 6 *}$ \\
\hline$* p<0.05$ & & &
\end{tabular}

${ }^{*} p<0.05$ 
Table 3. Plasma homocysteine and serum vitamin B12 and folic acid levels after methylprednisolone (MP) and interferon-beta- $1 \mathrm{~b}(\mathrm{INF}-\beta)$ treatments.

\begin{tabular}{lccc}
\hline$(\boldsymbol{n}=\mathbf{1 6})$ & Pre MP & Post INF- $\boldsymbol{\beta}$ & \\
& Mean \pm SD & Mean \pm SD & P* \\
\hline Homocysteine $(\mathbf{m m o l} / \mathbf{L})$ & $8.01 \pm 2.40$ & $8.69 \pm 2.40$ & 0.231 \\
Vitamin B12 $(\mathbf{p g} / \mathbf{m L})$ & $419.10 \pm 149.01$ & $445.32 \pm 168.12$ & 0.232 \\
Folic acid $(\mathbf{n g} / \mathbf{m L})$ & $7.27 \pm 1.61$ & $6.90 \pm 2.48$ & 0.779 \\
\hline
\end{tabular}

${ }^{*} p<0.05$ 
Table 4. Pre- and post-treatment plasma homocysteine and serum vitamin B12 and folic acid levels in patients who received interferon-beta (INF- $\beta$ ) alone.

\begin{tabular}{lccc}
\hline $\mathbf{n}=\mathbf{1 1})$ & Pre INF- $\beta$ & Post INF- $\beta$ & \\
& Mean \pm SD & Mean \pm SD & P* \\
\hline Homocysteine $(\mathbf{m m o l} / \mathbf{L})$ & $7.90 \pm 2.21$ & $7.34 \pm 1.88$ & 0.080 \\
Vitamin B12 $(\mathbf{p g} / \mathbf{m L})$ & $523.64 \pm 327.97$ & $505.06 \pm 189.30$ & 0.686 \\
Folic acid $(\mathbf{n g} / \mathbf{m L})$ & $8.79 \pm 3.57$ & $8.36 \pm 1.00$ & 0.893 \\
\hline
\end{tabular}

$* p<0.05$ 


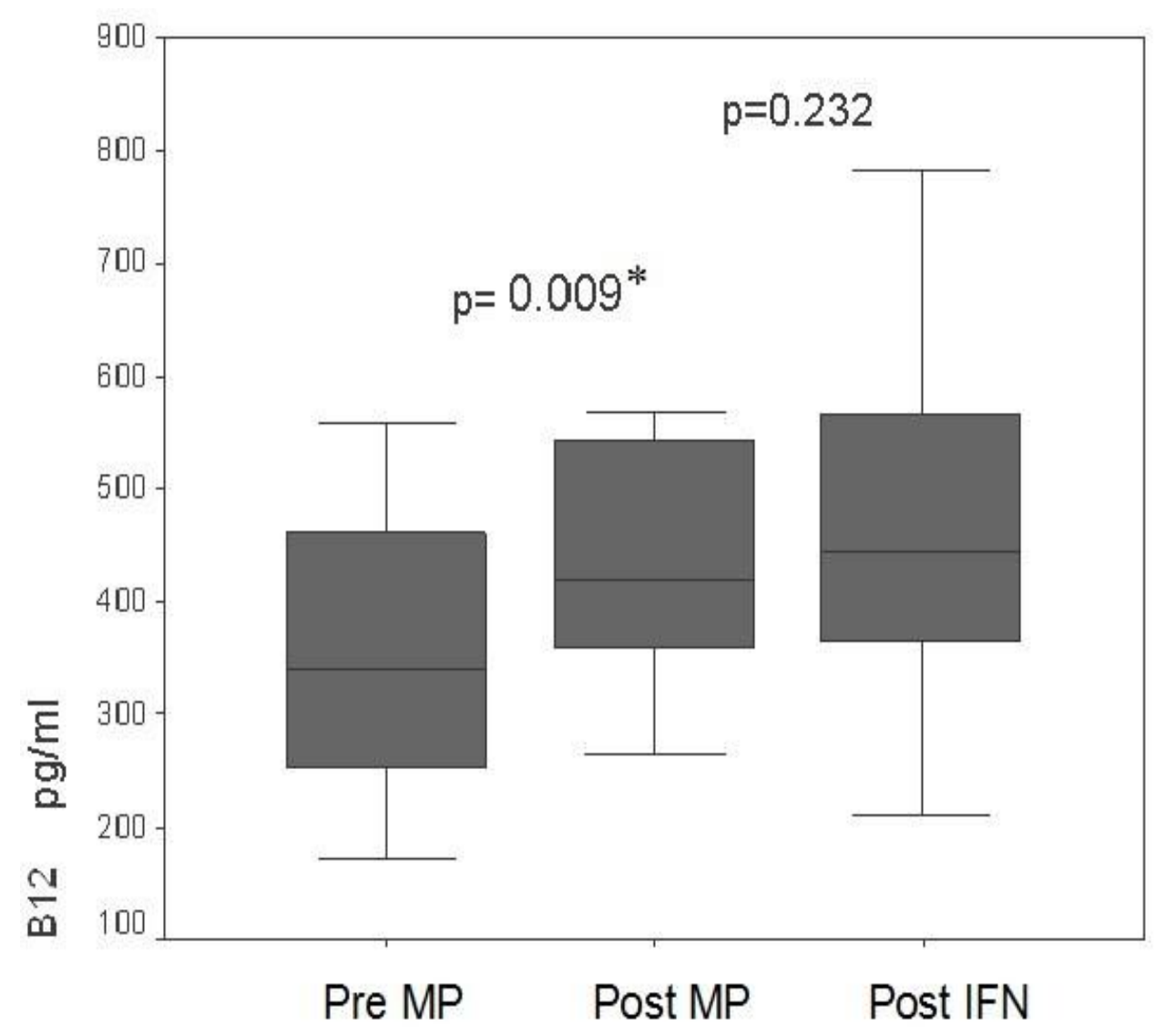

Figure 1. MP treatment significantly increased serum vitamin B12 levels compared to pre-MP $(p=$ 0.009), whereas the increase in serum vitamin B12 following treatment with INF- $\beta$ did not reach significance $* p<0.05$. 